\title{
Extraction-Chromogenic System for Nickel(II) Based on 5-methyl-4-(2-thiazolylazo)resorcinol and Aliquat 336
}

\author{
Galya Konstantinova Toncheva, ${ }^{1}$ Danail Georgiev Hristov, ${ }^{2}$ \\ Nikolina Petkova Milcheva ${ }^{2,3}$ and Kiril Blazhev Gavazov ${ }^{2,3, *}$ \\ ${ }^{1}$ Department of General and Inorganic Chemistry with Methodology of Chemical Education, \\ University of Plovdiv Paisii Hilendarski, 24 Tsar Assen St., Plovdiv 4000, Bulgaria \\ ${ }^{2}$ Department of Chemical Sciences, Medical University of Plovdiv, 120 Buxton Brothers St., Plovdiv 4004, Bulgaria \\ ${ }^{3}$ Research Institute at the Medical University of Plovdiv, Vasil Aprilov Bld., Plovdiv 4002, Bulgaria \\ *Corresponding author: E-mail: kgavazov@abv.bg
}

Received: 06-07-2019

\begin{abstract}
A water-isobutanol extraction-chromogenic system for $\mathrm{Ni}^{\mathrm{II}}$, based on the azo dye 5-methyl-4-(2-thiazolylazo)resorcinol (MTAR; $\mathrm{H}_{2} \mathrm{~L}$ ) and the ionic liquid Aliquat 336 (A336), was studied. Under the optimal conditions $\left(c_{\mathrm{MTAR}}=2.0 \times 10^{-4}\right.$ mol dm${ }^{-3}, c_{\mathrm{A} 336}=5.6 \times 10^{-3} \mathrm{~mol} \mathrm{dm}^{-3}, \mathrm{pH} 8.5$ and extraction time $\left.\mathrm{t}=1 \mathrm{~min}\right), \mathrm{Ni}^{\mathrm{II}}$ is extracted as a ternary complex which can be represented by the formula $\left(\mathrm{A}_{336}\right)_{2}\left[\mathrm{Ni}\left(\mathrm{L}^{2-}\right)_{2}\right]$. In the absence of $\mathrm{A} 336$, or in a slightly acidic medium, a binary complex, $\left[\mathrm{Ni}\left(\mathrm{HL}^{-}\right)_{2}\right]$, with an absorption maximum at $\lambda=548 \mathrm{~nm}$ and a shoulder at $590 \mathrm{~nm}$ is formed. The following extraction-spectrophotometric characteristics were determined at the above-mentioned optimal conditions: $\lambda_{\max }$ (545 $\mathrm{nm})$, molar absorptivity $\left(5.0 \times 10^{4} \mathrm{dm}^{3} \mathrm{~mol}^{-1} \mathrm{~cm}^{-1}\right)$, Sandell's sensitivity $\left(1.2 \times 10^{-3} \mu \mathrm{g} \mathrm{cm}{ }^{-2}\right)$, Beer's law limits $(0.05-3.1$ $\mu \mathrm{g} \mathrm{cm}^{-3}$ ), constant of extraction ( $\log K=6.1$ ) and fraction extracted $(99.2 \%)$. The effect of foreign ions was studied; the most serious interferences were caused by $\mathrm{Co}^{\mathrm{II}}$, $\mathrm{Cu}^{\mathrm{II}}$ and $\mathrm{Cr}^{\mathrm{III}}$.
\end{abstract}

Keywords: Nickel(II); 4-(2-thiazolylazo)orcinol; ternary complex; solvent extraction; low-toxic solvent; spectrophotometry

\section{Introduction}

Nickel is a first-row transition metal with many industrial applications ${ }^{1}$ and important functions in biology of microorganisms and plants. ${ }^{2}$ It is involved in a variety of products, such as stainless steels, alloys, rechargeable batteries, guitar strings, green colored glasses, permanent magnets and catalysts for large-scale industrial processes. Most of the nickel produced is used in stainless steels, ferrous and non-ferrous alloys and nickel plating. ${ }^{3}$ The chief criteria of use are its resistance to air oxygen, alkalis and acids, lustrous shine, ductility, malleability, and excellent ability to alloy with both ferrous and nonferrous metals. Over 3000 alloys containing nickel are known. They have more than 250000 applications. ${ }^{4}$

In the earth's crust, nickel occurs most often in combination with sulfur, iron and arsenic. It is found in all types of soils, in fossil fuels, marine sediments, volcanic emissions and iron meteorites. Anthropogenic activities that contribute to nickel loadings in the environment include burning of fuel and residual oil, mining, smelting, refining, alloy processing, scrap metal reprocessing, waste incineration and disposal of sewage sludge or application of sludge as a fertilizer. ${ }^{4-6}$

It is known that nickel may have carcinogenic, mutagenic and allergic properties. ${ }^{7}$ Negative health effects have been documented for respiratory, cardiovascular, gastrointestinal, hematological, musculoskeletal, hepatic, renal, dermal, ocular, immunological, developmental, neurological and reproductive systems. ${ }^{6}$ An allergic skin reaction is a common problem for some people; it is often associated with the presence of nickel in daily-used objects, such as jewelry, keys, jean buttons, children's clothing and toys. ${ }^{8,9}$

Many analytical techniques, such as atomic absorption spectrophotometry, optical emission spectrometry, $\mathrm{X}$-ray fluorescence analysis, neutron activation analysis, voltammetry and spectrophotometry, have been used for 
nickel determination. ${ }^{10-14}$ The methods involving spectrophotometry are simple and low-cost; they can be easily combined with procedures for preliminary separation and concentration, such as cloud point extraction, ${ }^{13}$ solid phase extraction ${ }^{14}$ and liquid-liquid extraction (LLE). ${ }^{15-20}$

5-methyl-4-(2-thiazolylazo)resorcinol (MTAR) is a well-known analytical reagent. ${ }^{21-28}$ It has recently been used in our laboratory for LLE of $\mathrm{V}^{\mathrm{IV}, \mathrm{V}} .{ }^{29-32}$ Here, we describe investigations on a LLE-chromogenic system for $\mathrm{Ni}^{\mathrm{II}}$ containing MTAR and the ionic liquid Aliquat 336 (A336). The selected organic solvent was isobutanol (2-methylpropan-1-ol). It is characterized by a low toxicity, volatility and corrosivity, ${ }^{33,34}$ can be produced from renewable resources, ${ }^{35}$ fulfills the so-called " $\mathrm{CHON}$ principle"36 and is readily biodegradable and non-bioaccumulative. ${ }^{33,37}$

\section{Materials and Methods}

\section{1. Reagents and Apparatus}

Stock solution of $\mathrm{Ni}^{\mathrm{II}}\left(1.7 \times 10^{-2} \mathrm{~mol} \mathrm{dm}^{-3} ; \mathrm{pH} \sim 2\right)$ was prepared by dissolving $\mathrm{NiSO}_{4} \sim 7 \mathrm{H}_{2} \mathrm{O}$ (Sigma-Aldrich, $99.999 \%$ trace metals basis) in distilled water containing $\mathrm{H}_{2} \mathrm{SO}_{4}$. Working solutions $\left(2 \times 10^{-4} \mathrm{~mol} \mathrm{dm}^{-3}\right)$ were prepared by appropriate dilution of the stock solution. MTAR (95\%, Sigma-Aldrich Chemie $\mathrm{GmbH}$ ) was dissolved in the presence of $\mathrm{KOH} ;{ }^{31}$ the obtained slightly alkaline aqueous solution $(\mathrm{pH} \mathrm{8-9)}$ was at concentration of $2 \times 10^{-3} \mathrm{~mol} \mathrm{dm}^{-3}$. Aliquat 336 was purchased from Sigma-Aldrich Chemie and dissolved in isobitanol (p. a., Merck). Solutions with concentrations of $1.4 \times 10^{-2}$ and $5.6 \times 10^{-3} \mathrm{~mol} \mathrm{dm}^{-3}$ were used; the calculations were based on the average molar mass of A336 $\left(432 \mathrm{~g} \mathrm{~mol}^{-1}\right) .^{38}$ The acidity of the aqueous medium was set by the addition of buffer solution, prepared by $2 \mathrm{~mol} \mathrm{dm}^{-3}$ solutions of $\mathrm{CH}_{3} \mathrm{COOH}$ and ammonia. The $\mathrm{pH}$ of the buffers was measured by a WTW InoLab 7110 (Germany) pH meter with an accuracy of $\pm 0.001 \mathrm{pH}$ units. Absorbance measurements were made with a Camspec M508 and a Ultrospec3300 pro UV-Vis spectrophotometers (UK), equipped with $1 \mathrm{~cm}$ path-length glass cells. Distilled water was used throughout the work.

\section{2. Determination of the Optimum Conditions}

Solutions of $\mathrm{Ni}^{\mathrm{II}}$, MTAR and buffer were placed into a separatory funnel. The aqueous phase volume was adjusted to $5 \mathrm{~cm}^{3}$ or $10 \mathrm{~cm}^{3}$ with water. A portion of the A336 solution was added and the organic phase was adjusted to $5 \mathrm{~cm}^{3}$ with isobutanol. Then the funnel was shaken for a fixed time interval (between 5 and 300 seconds). After separation of the phases, the aqueous layer was discarded, and the organic layer was transferred into a beaker. A pinch of anhydrous $\mathrm{Na}_{2} \mathrm{SO}_{4}$ was added to remove any water and the colored solution was poured into the spectrophotometer cell. The absorbance was measured against isobutanol or simultaneously prepared blank sample.

\section{3. Determination of the Distribution Ratio}

The distribution ratio $D$ was calculated by the formula $D=A_{1} /\left(A_{3}-A_{1}\right)$, where $A_{1}$ is the absorbance obtained after a single extraction under the optimal $\mathrm{pH}$ and reagents concentrations (Table 1) and $A_{3}$ is the absorbance obtained after a triple extraction..$^{30,31}$ The single extraction and the first stage of the triple extraction were performed with equal volumes of both phases $\left(5 \mathrm{~cm}^{3}\right)$. The organic layers were transferred into two $25-\mathrm{cm}^{3}$ calibrated flasks and the flask for the single extraction was brought to volume with the isobutanol solution of A336 $\left(5.6 \times 10^{-3} \mathrm{~mol} \mathrm{dm}^{-3}\right)$. The second stage of the triple extraction was performed by adding a $5-\mathrm{cm}^{3}$ portion of the A336 solution to the aqueous phase which remained after the first stage. The third stage was performed in the same manner. The two successive organic layers were transferred to the flask with the isobutanol extract obtained after the first stage. The volume was brought to the mark with the A336 solution. Absorbances $A_{1}$ and $A_{3}$ were measured against corresponding blanks.

\section{4. Investigation of the Influence of Foreign Ions}

Solutions of $\mathrm{Ni}^{\mathrm{II}}\left(1 \mathrm{~cm}^{3}, 2 \times 10^{-4} \mathrm{~mol} \mathrm{dm}^{-3}\right)$, foreign ion, MTAR $\left(1 \mathrm{~cm}^{3}, 2 \times 10^{-3} \mathrm{~mol} \mathrm{dm}{ }^{-3}\right)$ and buffer $\left(1 \mathrm{~cm}^{3}\right.$, $\mathrm{pH} 8.5$ ) were successively placed into a separatory funnel. The aqueous phase volume was adjusted to $10 \mathrm{~cm}^{3}$ with

Table 1. LLE-spectrophotometric optimization of the $\mathrm{Ni}^{\mathrm{II}}$ - MTAR - A336 - water - isobutanol system. The volume of the organic phase was $5 \mathrm{~cm}^{3}$.

\begin{tabular}{|c|c|c|}
\hline Parameter & Optimization range & Optimal value \\
\hline Wavelength, $\mathrm{nm}$ & Visible range & 545 \\
\hline $\mathrm{pH}$ & $3.9-9.9$ & 8.5 \\
\hline Volume of the aqueous phase, $\mathrm{cm}^{-3}$ & 5 and 10 & 10 \\
\hline Concentration of MTAR, $\mathrm{mol} \mathrm{dm}^{-3}$ & $(0-1.6) \times 10^{-3}$ & $2.0 \times 10^{-4}$ \\
\hline Concentration of A336, $\mathrm{mol} \mathrm{dm}^{-3}$ & $(0-1.4) \times 10^{-2}$ & $5.6 \times 10^{-3}$ \\
\hline Extraction time, seconds & 5-300 & 60 \\
\hline
\end{tabular}

Toncheva et al.: Extraction-Chromogenic System for Nickel(II) ... 
water. Then A336 solution $\left(5 \mathrm{~cm}^{3}, 5.6 \times 10^{-3} \mathrm{~mol} \mathrm{dm}^{-3}\right)$ was added and the funnel was shaken for $1 \mathrm{~min}$. The organic layer was transferred into a beaker, dried with a pinch of anhydrous $\mathrm{Na}_{2} \mathrm{SO}_{4}$ and poured into the spectrophotometer cell. The absorbance was measured at $545 \mathrm{~nm}$ against isobutanol. For control, samples prepared by the same procedure in the absence of the foreign ion or $\mathrm{Ni}^{\mathrm{II}}$ were also run.

\section{Results and Discussion}

\section{1. Absorption Spectra of the Isobutanol- Extracted Complexes}

Spectra of isobutanol-extracted Ni-MTAR complexes in the presence $(1,3)$ or absence $(2,4)$ of A336 are shown in Fig. 1 . The spectra 1 and 2 are alike $\left(1: \lambda_{\max }=545\right.$ $\mathrm{nm} ; 2: \lambda_{\max }=548 \mathrm{~nm}$ ), however in absence of A336 (2) the absorbance is lower, and a shoulder at about $590 \mathrm{~nm}$ is observed. Such a shoulder is slightly visible in spectrum 1. There is a tendency for it to become more and more imperceptible with increasing $\mathrm{pH}$ and decreasing the MTAR concentration.

At lower $\mathrm{pH}$ values (4.7; spectra 3 and 4), nickel is extracted to a negligible extent regardless of the presence or absence of A336. The absorbance of the blanks in the absence of A336 (2' and 4') is lower than that obtained in the presence of A336 (1' and 3', respectively). This can be explained by the formation of an extractable ion pair between the anion of the azo dye $\left(\mathrm{HL}^{-}\right)^{31,39,40}$ and the cation of the ionic liquid $\left(\mathrm{A} 336^{+}\right)$.

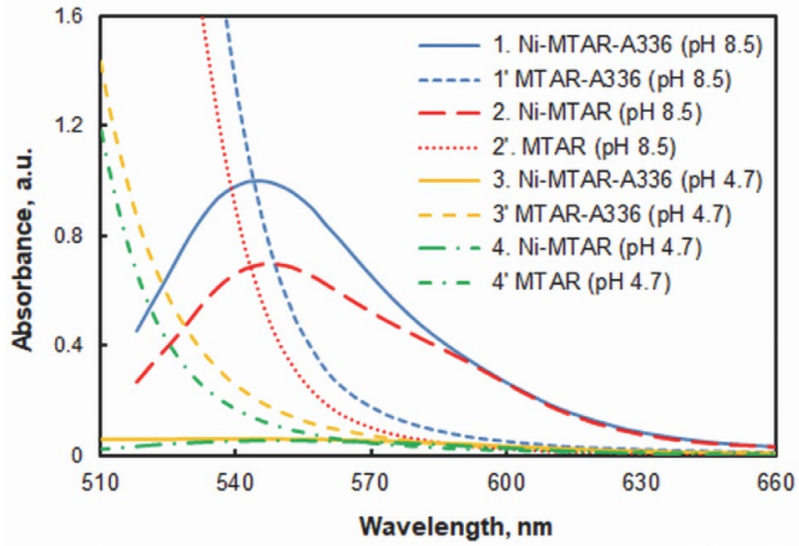

Figure 1. Absorption spectra in isobutanol of complexes against blanks $\left(1-4 ; c_{\mathrm{Ni}}=2 \times 10^{-5} \mathrm{~mol} \mathrm{dm}{ }^{-3}, c_{\mathrm{MTAR}}=2.7 \times 10^{-4} \mathrm{~mol} \mathrm{dm}^{-3}\right.$, $c_{\mathrm{A} 366}=5.6 \times 10^{-3} \mathrm{~mol} \mathrm{dm}{ }^{-3}, V_{\text {aq. phase }}=10 \mathrm{~cm}^{3}$, extraction time $\mathrm{t}=$ $60 \mathrm{sec})$ and corresponding blanks against isobutanol (1' - 4'). Samples 2, 2', 4 and 4' do not contain $\mathrm{A} 336$; $\mathrm{pH}$ is given in the legend.

\section{2. Effect of $\mathbf{p H}$}

The effect of $\mathrm{pH}$ on the absorbance obtained in the presence or absence of A336 is shown in Fig. 2. Ammo- nia-acetate buffer solutions, which have the best buffering action at $\mathrm{pH} 4.75$ (the $\mathrm{pK}_{\mathrm{a}}$ of acetic acid) and 9.25 (the $\mathrm{pK}_{\mathrm{a}}$ of $\left.\mathrm{NH}_{4}{ }^{+}\right)^{41}$ were used in all experiments. In the presence of A336 (series 1), maximal absorbance was obtained in slightly alkaline medium. The sharp decrease at $\mathrm{pH}<6$ can be attributed to incomplete complex formation due to the predominance of doubly protonated MTAR species. ${ }^{42}$ In the absence of A336 (series 2), maximal absorbance was recorded in the slightly acidic region ( $\mathrm{pH} c a .6 .5-7.0)$. It makes sense that the course of series 1 and series 2 is identical in the acidic region (up to $\mathrm{pH} c a .6$ ); probably the absorbance obtained in the presence of A336 is due to the simultaneous extraction of two complexes, Ni-MTARA336 and Ni-MTAR. However, with the increase in $\mathrm{pH}$, the contribution of the ternary complex to the total absorbance becomes greater.

The decrease in absorbance at $\mathrm{pH}>c a .9$ (series 1$)$ can be attributed to two factors: (i) presence of hydrolyzed $\mathrm{Ni}(\mathrm{OH})^{+}$species; ${ }^{43}$ and (ii) a competitive extraction of the $\left(\mathrm{A} 336^{+}\right)\left(\mathrm{HL}^{-}\right)$ion pair which reduces the effective concentrations of the reagents to a larger extent at higher $\mathrm{pH}$ values (see spectra 1' and 3' in Fig. 1).

One can conclude from Fig. 2, and from the above mentioned $\mathrm{pK}_{\mathrm{a}}$ value of $\mathrm{NH}_{4}{ }^{+}(9.25)$, that the optimal $\mathrm{pH}$ range for the extraction of $\mathrm{Ni}^{\mathrm{II}}$ is 8.3-9.0. We performed our further investigations at $\mathrm{pH} 8.5$.

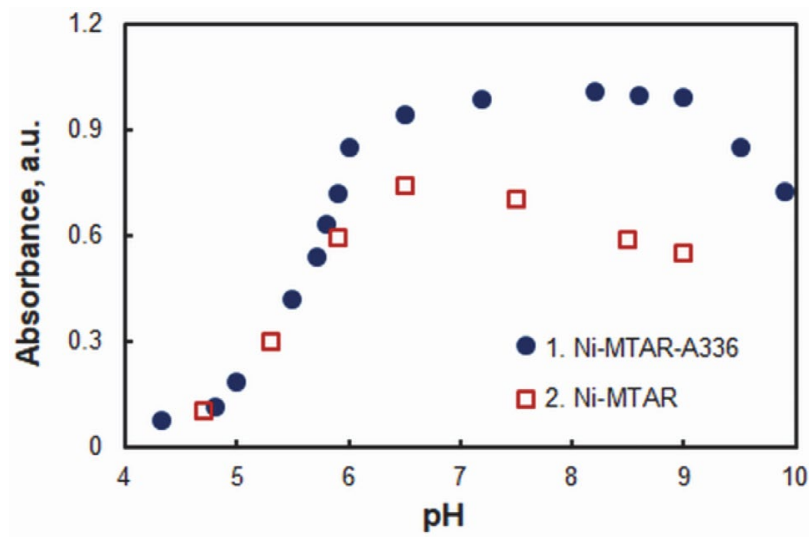

Figure 2. Absorbance of the complex in presence (1) or absence (2) of A336 vs. pH of the aqueous phase. $c_{\mathrm{Ni}}=2 \times 10^{-5} \mathrm{~mol} \mathrm{dm}^{-3}, c_{\mathrm{MTAR}}$ $=2 \times 10^{-4} \mathrm{~mol} \mathrm{dm}^{-3}, c_{\mathrm{A} 366}=5.6 \times 10^{-3} \mathrm{~mol} \mathrm{dm}^{-3}, V_{\text {aq. phase }}=10 \mathrm{~cm}^{3}$, extraction time $\mathrm{t}=60 \mathrm{sec}$.

\section{3. Effect of the Reagents Concentrations, Volume of the Aqueous Phase and Shaking Time}

The effect of the MTAR concentration on the absorbance is shown in Fig. 3 for two different sets of conditions. There is a maximum in both series; at high concentrations of MTAR, the absorption decreases. With a 2:1 volume ratio (series $2 ; 10 \mathrm{~cm}^{3}$ aqueous phase $/ 5 \mathrm{~cm}^{3}$ isobutanol phase), the apparent molar absorptivity is high- 
er. The optimal reagent concentration for this volume ratio appears to be $c_{\text {MTAR }}=2.0 \times 10^{-4} \mathrm{~mol} \mathrm{dm}^{-3}$. It is considerably lower (by almost an order of magnitude) than the MTAR concentration required for the extraction of $\mathrm{V}^{\mathrm{V}} .31$

The effect of the A336 concentration on the absorbance is shown in Fig. 4 . The optimal concentration is $c_{\mathrm{A} 336}$ $=5.6 \times 10^{-3} \mathrm{~mol} \mathrm{dm}^{-3}$. It is also lower than that required for the extraction of $\mathrm{V}^{\mathrm{V}} ;{ }^{31}$ this indicates that the $\mathrm{Ni}^{\mathrm{II}}$ MTAR-A336 complex is more stable than the corresponding $\mathrm{V}^{\mathrm{V}}$ complex.

The effect of shaking time was studied under the optimal $\mathrm{pH}$ and reagents concentrations (Table 1). It was found that 50 seconds are enough for a quantitative extraction of $\mathrm{Ni}^{\mathrm{II}}$. To avoid accidental errors, induced by the combination of short shaking times and different shaking rates, we shook for 60 seconds in our further experiments.

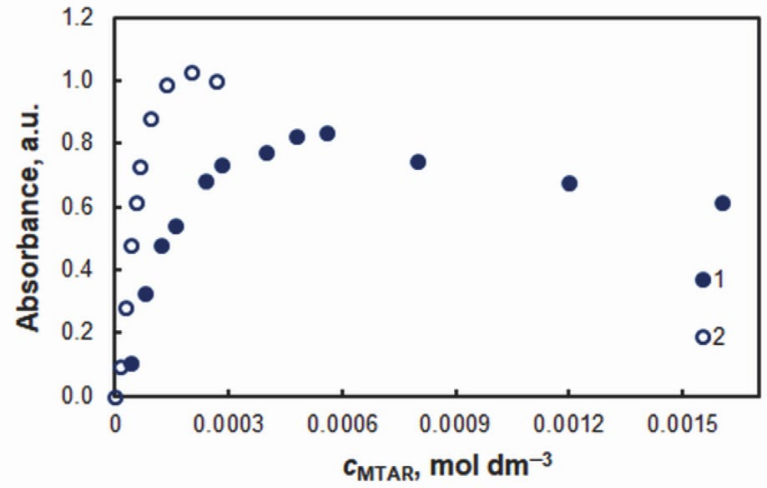

Figure 3. Absorbance vs. concentration of MTAR. (1) $c_{\mathrm{Ni}}=4 \times 10^{-5}$ mol dm ${ }^{-3}, c_{\mathrm{A} 366}=1.4 \times 10^{-2} \mathrm{~mol} \mathrm{dm}^{-3}, \mathrm{pH} 6, V_{\text {aq. phase }}=5 \mathrm{~cm}^{3}$, extraction time $\mathrm{t}=60 \mathrm{sec} ;(2) c_{\mathrm{Ni}}=2 \times 10^{-5} \mathrm{~mol} \mathrm{dm}^{-3}, c_{\mathrm{A} 366}=5.6 \times$ $10^{-3} \mathrm{~mol} \mathrm{dm}^{-3}, \mathrm{pH} 8.5, V_{\text {aq. phase }}=10 \mathrm{~cm}^{3}$, extraction time $\mathrm{t}=60 \mathrm{sec}$.

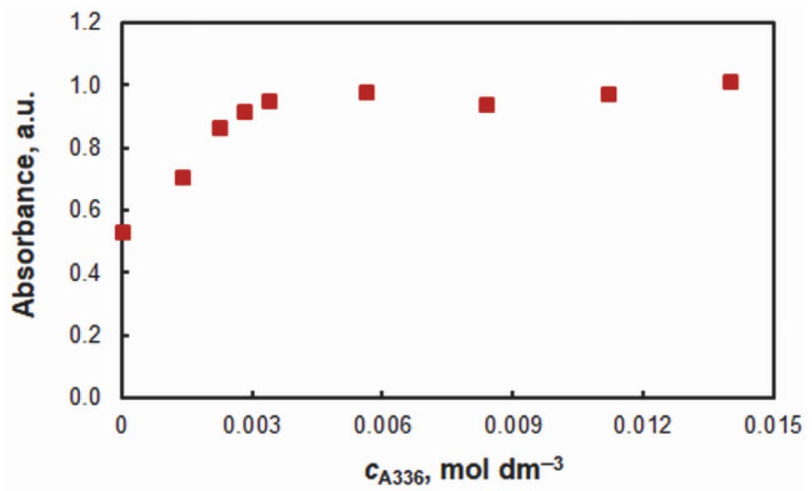

Figure 4. Absorbance vs. concentration of A336. $c_{\mathrm{Ni}}=2 \times 10^{-5} \mathrm{~mol}$ $\mathrm{dm}^{-3}, c_{\mathrm{MTAR}}=2.0 \times 10^{-4} \mathrm{~mol} \mathrm{dm}{ }^{-3}, \mathrm{pH} 8.5, V_{\text {aq. phase }}=10 \mathrm{~cm}^{3}, \mathrm{ex}-$ traction time $\mathrm{t}=60 \mathrm{sec}$.

\section{4. Molar Ratios, Structure and Equations of Complex Formation and Extraction}

It is known that thiazolylazo- and pyridylazo dyes form $1: 1^{44}$ or $1: 2^{45-48}$ complexes with $\mathrm{Ni}^{\mathrm{II}}$. In aqueous medium, at least two different 1:2 Ni-to-PAR complex species
(PAR $=\mathrm{H}_{2} \mathrm{~L}=4$-(2-pyridylazo)resorcinol) exist, $[\mathrm{Ni}(\mathrm{HL})$ $\mathrm{L}]^{-}$and $\left[\mathrm{NiL}_{2}\right]^{2-} \cdot{ }^{49}$ In the presence of a quaternary ammonium salt (tetradecyldimethylbenzylammonium chloride; $\left.\mathrm{Q}^{+} \mathrm{Cl}^{-}\right),{ }^{50}$ two kinds of complexes can be extracted in chloroform, $\left[\mathrm{Ni}(\mathrm{HL})_{2}\right] \cdot \mathrm{n}\left(\mathrm{Q}^{+} \mathrm{Cl}^{-}\right)$and $\left(\mathrm{Q}^{+}\right)_{2}\left[\mathrm{NiL}_{2}\right]$; the second one has a higher molar absorptivity. Karipcin et al. isolated in solid state water-insoluble octahedral 1:2 binary complexes with $\mathrm{PAR}^{47}$ or 4-(2-thiazolylazo)resorcinol (TAR); ${ }^{48}$ they can be represented by the general formula $\left[\mathrm{Ni}(\mathrm{HL})_{2}\right]$. The TAR complex is partially soluble in chloroform and readily soluble in alcohols; in ethanol, it shows an absorption maximum at $543 \mathrm{~nm}$ and a shoulder at $586 \mathrm{~nm} .{ }^{48}$

It is clear from our investigations (see Fig. 1, Fig 2 and Fig. 4) that at least two different $\mathrm{Ni}^{\mathrm{II}}-$ MTAR isobutanol-extractable complexes exist: (i) a binary Ni-MTAR complex; it is extracted in the absence of A336 (Fig. 1, spectrum 1); and (ii) a ternary Ni-MTAR-A336 complex (Fig. 1, spectrum 2). The MTAR:Ni ${ }^{\mathrm{II}}$ and $\mathrm{A} 336: \mathrm{Ni}^{\mathrm{II}}$ molar ratios in the ternary complex were determined by the straight-line method of
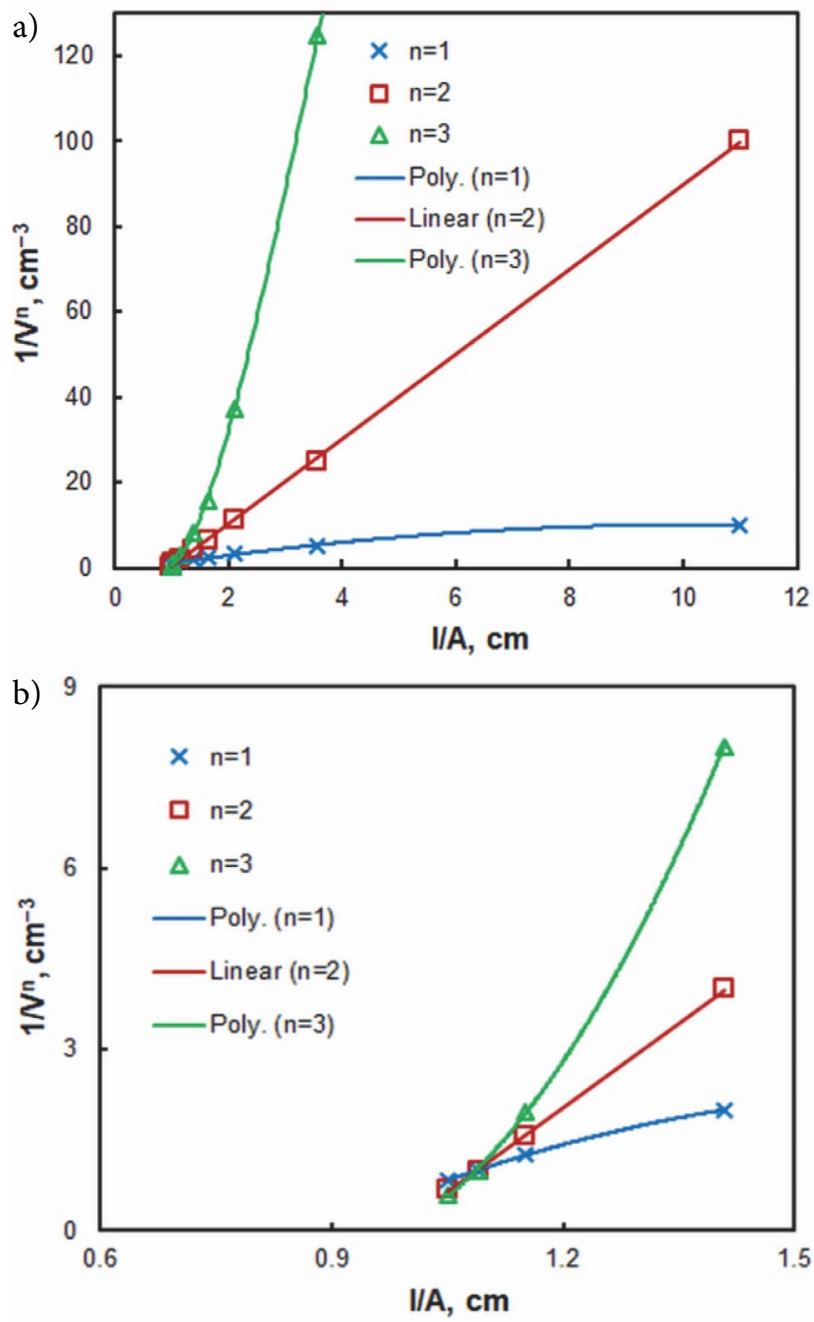

Figure 5. Determination of the MTAR/ $/ \mathrm{Ni}^{\mathrm{II}}(\mathbf{a})$ and $\mathrm{A} 336 / \mathrm{Ni}^{\mathrm{II}}(\mathbf{b})$ molar ratios by the straight-line method of Asmus. The experimental conditions are given in Fig. 3 (series 2 ) and Fig. 4, respectively. 
Asmus $^{51}$ (Fig. 5) and the mobile equilibrium method ${ }^{52}$ (Fig. 6). Its formation and extraction can be represented by Eq. 1 .

$$
\begin{aligned}
& \mathrm{Ni}^{2+}{ }_{(\mathrm{aq})}+2 \mathrm{HL}^{-}{ }_{(\mathrm{aq})}+2 \mathrm{~A}^{2} 36^{+}{ }_{(\mathrm{org})} \rightleftarrows \\
& \left(\mathrm{A} 336^{+}\right)_{2}\left[\mathrm{Ni}(\mathrm{L})_{2}\right]_{(\mathrm{org})}+2 \mathrm{H}^{+}{ }_{(\mathrm{aq})}
\end{aligned}
$$

In the absence of $\mathrm{A} 336$, a neutral $\left[\mathrm{Ni}(\mathrm{HL})_{2}\right]$ complex is formed (Eq. 2).

$$
\mathrm{Ni}^{2+}{ }_{(\mathrm{aq})}+2 \mathrm{HL}^{-}{ }_{(\mathrm{aq})} \rightleftarrows\left[\mathrm{Ni}(\mathrm{HL})_{2}\right]_{(\mathrm{org})}
$$

As mentioned above, a complex with the same formula (which is insoluble in water and soluble in alcohols)

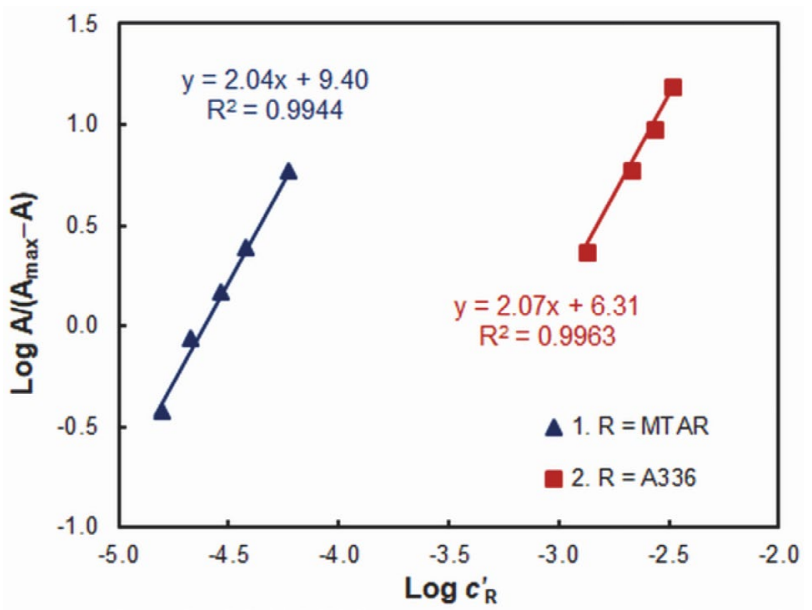

Figure 6. Determination of the MTAR/ $\mathrm{Ni}^{\mathrm{II}}$ (1) and $\mathrm{A} 336 / \mathrm{Ni}^{\mathrm{II}}$ (2) molar ratios by the mobile equilibrium method. The experimental conditions are given in Fig. 3 (series 2) and Fig. 4, respectively. has been prepared with TAR. ${ }^{48}$ The MTAR complex obtained by us has similar spectral characteristics (an absorption maximum of $548 \mathrm{~nm}$ and a shoulder at about 590 $\mathrm{nm}$ ), indicating that it probably has a similar structure. Most likely, both MTAR complexes, $\left[\mathrm{Ni}(\mathrm{HL})_{2}\right]$ and $\left(\mathrm{A} 336^{+}\right)_{2}\left[\mathrm{Ni}(\mathrm{L})_{2}\right]$, have an octahedral geometry which is common for $\mathrm{Ni}^{\mathrm{II}}$ centers. ${ }^{47,48,53,54}$ Donor atoms of each of the tridentate MTAR units should be the o-hydroxyl oxygen (relative to the azo-group) and the two nitrogens (from the thiazole ring and azo-group). ${ }^{47,48,55}$

As shown in Eqs. 1 and 2, MTAR at the operating conditions exists mainly in its $\mathrm{HL}^{-}$form (with a proton in the $\mathrm{OH}$-group in ortho-position relative to the azogroup). ${ }^{42,56}$ It is known that this form dominates (in aqueous medium) at the $\mathrm{pH}$ range of $5.7-11.8 .^{42}$

\section{5. Beer's Law and Analytical Characteristics}

The dependence between the concentration of $\mathrm{Ni}^{\mathrm{II}}$ in the aqueous phase and the absorbance of the extract was studied under the optimal conditions (Table 1). A good linearity was obtained in the range of $0.05-3.1 \mu \mathrm{g} \mathrm{cm}^{-3}$ $\left(R^{2}=0.9993, \mathrm{~N}=9\right)$. The linear regression equation was $A$ $=0.845 \gamma-0.006$, where $A$ is the absorbance and $\gamma$ is the concentration $\left(\mu \mathrm{g} \mathrm{cm}^{-3}\right)$ of $\mathrm{Ni}^{\mathrm{II}}$. The standard deviations of the slope and intercept were 0.008 and 0.013 , respectively. The limits of detection (LOD) and quantitation (LOQ), calculated as 3- and 10-times standard deviation of the intercept divided by the slope, were LOD $=46 \mathrm{ng} \mathrm{cm}^{-3}$ and LOQ $=153 \mathrm{ng} \mathrm{cm}^{-3}$. The molar absorptivity $(\varepsilon)$ and Sandell's sensitivity (S) at $\lambda_{\max }=545 \mathrm{~nm}$ were $\varepsilon=5.0 \times 10^{4} \mathrm{dm}^{3}$

\begin{tabular}{|c|c|c|c|c|}
\hline $\begin{array}{l}\text { Foreign ion } \\
\text { (FI) added }\end{array}$ & $\begin{array}{c}\text { Added } \\
\text { salt }\end{array}$ & $\begin{array}{c}\mathrm{FI}: \mathrm{Ni}^{\mathrm{II}} \\
\text { mass ratio }\end{array}$ & $\begin{array}{r}\text { Amount } \\
(\mu \mathrm{g})\end{array}$ & $\begin{array}{l}\text { II found } \\
(\%)\end{array}$ \\
\hline $\mathrm{Al}^{\mathrm{III}}$ & $\mathrm{Al}_{2}\left(\mathrm{SO}_{4}\right)_{3} \cdot 18 \mathrm{H}_{2} \mathrm{O}$ & 8.5 & 11.4 & 97.4 \\
\hline $\mathrm{Br}^{-}$ & $\mathrm{NaBr}$ & 850 & 11.7 & 100 \\
\hline $\mathrm{Cd}^{\mathrm{II}}$ & $\mathrm{CdCl}_{2}$ & 5 & 12.3 & 105 \\
\hline $\mathrm{Cl}^{-}$ & $\mathrm{NH}_{4} \mathrm{Cl}$ & 850 & 11.8 & 101 \\
\hline $\mathrm{Co}^{\mathrm{II}}$ & $\mathrm{CoSO}_{4} \cdot 7 \mathrm{H}_{2} \mathrm{O}$ & 1 & 17.0 & 146 \\
\hline $\mathrm{Cr}^{\mathrm{III}}$ & $\mathrm{Cr}_{2}\left(\mathrm{SO}_{4}\right)_{3}$ & 1 & 8.42 & 72.0 \\
\hline $\mathrm{Cr}^{\mathrm{VI}}$ & $\mathrm{K}_{2} \mathrm{CrO}_{4}$ & 500 & 11.9 & 101 \\
\hline $\mathrm{Cu}^{\mathrm{II}}$ & $\mathrm{CuSO}_{4} \cdot 5 \mathrm{H}_{2} \mathrm{O}$ & 1 & 16.1 & 138 \\
\hline $\mathrm{F}^{-}$ & $\mathrm{NH}_{4} \mathrm{~F}$ & 850 & 10.6 & 99.4 \\
\hline $\mathrm{Fe}^{\mathrm{III}}$ & $\mathrm{Fe}_{2}\left(\mathrm{SO}_{4}\right)_{3}$ & 5 & 12.3 & 105 \\
\hline $\mathrm{HPO}_{4}{ }^{2-}$ & $\mathrm{Na}_{2} \mathrm{HPO}_{4}$ & 500 & 11.8 & 101 \\
\hline $\mathrm{I}^{-}$ & KI & 250 & 11.1 & 95.1 \\
\hline $\mathrm{Mg}^{\mathrm{II}}$ & $\mathrm{MgSO}_{4}$ & 500 & 11.7 & 100 \\
\hline $\mathrm{Mn}^{\mathrm{II}}$ & $\mathrm{MnSO}_{4} \cdot 5 \mathrm{H}_{2} \mathrm{O}$ & 5 & 11.7 & 100 \\
\hline $\mathrm{Mo}^{\mathrm{VI}}$ & $\left(\mathrm{NH}_{4}\right)_{6} \mathrm{Mo}_{7} \mathrm{O}_{24} \cdot 4 \mathrm{H}_{2} \mathrm{O}$ & 100 & 11.7 & 100 \\
\hline $\mathrm{NO}_{3}{ }^{-}$ & $\mathrm{NH}_{4} \mathrm{NO}_{3}$ & 850 & 10.4 & 97.2 \\
\hline $\mathrm{Re}^{\mathrm{VII}}$ & $\mathrm{NH}_{4} \mathrm{ReO}_{4}$ & 400 & 11.5 & 98.2 \\
\hline $\mathrm{V}^{\mathrm{V}}$ & $\mathrm{NH}_{4} \mathrm{VO}_{3}$ & 5 & 12.0 & 103 \\
\hline $\mathrm{W}^{\mathrm{VI}}$ & $\mathrm{Na}_{2} \mathrm{WO}_{4} \cdot 2 \mathrm{H}_{2} \mathrm{O}$ & 500 & 12.0 & 103 \\
\hline $\mathrm{Zn}^{\mathrm{II}}$ & $\mathrm{ZnSO}_{4} \cdot 7 \mathrm{H}_{2} \mathrm{O}$ & 1 & 12.5 & 107 \\
\hline
\end{tabular}
$\mathrm{mol}^{-1} \mathrm{~cm}^{-1}$ and $\mathrm{S}=1.2 \times 10^{-3} \mu \mathrm{g} \mathrm{cm}^{-2}$, respectively.

Table 2. Effect of foreign ions in determination of $11.7 \mu \mathrm{g}$ of $\mathrm{Ni}^{\mathrm{II}}$. 
The distribution ratio $D$ was calculated from the absorbances obtained after single and triple extractions as described above: $D=121 \pm 3$ (six replicate measurements). The fraction extracted, $E=99.2 \%$, was found by the formula $E \%=100 \times D /(D+1)$. The conditional equilibrium constant characterizing Eq. 1 was calculated by the mobile equilibrium method ${ }^{52}$ (Fig. 5, straight line 2; abscissa intercept). The obtained value was $\log K=6.1 \pm 0.2$.

\section{6. Effect of Foreign Ions}

Various salts were used to test the selectivity of the developed procedure. Their effect is summarized in Table 2. The most significant interferences were those of $\mathrm{Co}^{\mathrm{II}}$, $\mathrm{Cu}^{\mathrm{II}}$ and $\mathrm{Cr}^{\mathrm{III}}$ which form intensively colored complexes under the specified conditions. Cr ${ }^{\mathrm{III}}$ causes a negative error, while $\mathrm{Co}^{\mathrm{II}}$ and $\mathrm{Cu}^{\mathrm{II}}$ cause positive errors. $\mathrm{Zn}^{\mathrm{II}}$ also causes positive errors, however its interfering effect is smaller. A 250 -fold excess of $\mathrm{I}^{-}$; 100 -fold excess of $\mathrm{Mo}^{\mathrm{VI}}$; 8.5-fold excess of $\mathrm{Al}^{\mathrm{III}}$; and 5 -fold excess of $\mathrm{V}^{\mathrm{V}}, \mathrm{Fe}^{\mathrm{III}}, \mathrm{Cd}^{\mathrm{II}}$ and $\mathrm{Mn}^{\mathrm{II}}$ are tolerable. The determination of $\mathrm{Ni}^{\mathrm{II}}$ is not affected by high concentrations of alkali and alkaline-earth ions, $\mathrm{NH}_{4}^{+}, \mathrm{Cl}^{-}, \mathrm{Br}^{-}, \mathrm{F}^{-}, \mathrm{NO}_{3}^{-}, \mathrm{SO}_{4}{ }^{2-}, \mathrm{CrO}_{4}{ }^{2-}, \mathrm{WO}_{4}{ }^{2-}$, $\mathrm{ReO}_{4}{ }^{-}$and $\mathrm{HPO}_{4}{ }^{2-}$.

\section{Conclusions}

The described investigations shed light on the complex formation between $\mathrm{Ni}^{\mathrm{II}}$ and MTAR in the presence or absence of A336. The conditions of existence of the two main extracted complexes, $\left(\mathrm{A} 336^{+}\right)_{2}\left[\mathrm{Ni}(\mathrm{L})_{2}\right]$ and $\left[\mathrm{Ni}(\mathrm{HL})_{2}\right]$, have been outlined and the differences in their spectra have been highlighted. In a slightly alkaline medium, $\mathrm{Ni}^{\mathrm{II}}$ predominantly forms a ternary complex. It is intensively colored and readily extractable into isobutanol. This solvent is less toxic than the diluents commonly applied to improve the physico-chemical characteristics of the ionic liquid A336 (e.g., benzene, ${ }^{57}$ carbon tetrachloride, ${ }^{58}$ chloroform, ${ }^{58}$ toluene, ${ }^{59}$ xylene $^{60}$ and kerosene ${ }^{61}$ ) and the organic solvents typically used for LLE-spectrophotometric determination of $\mathrm{Ni}^{\mathrm{II}}$ (e.g., chloroform). ${ }^{17-20}$

\section{Acknowledgments}

This work was supported by the Research Fund of the University of Plovdiv "Paisii Hilendarski" (Grant No SP19-HF009).

\section{References}

1. K. K. Chatterjee, Uses of Metals and Metallic Minerals, New Age International (P) Ltd. Publishers, New Delhi, India, 2007, pp. 272-275.
2. P. H. Brown, in: A. V Barker, D. J. Pilbeam (Ed.): Handbook of Plant Nutrition, CRC Press, Boca Raton, USA, 2007, pp 395-409.

3. A. Apostolikas, E. Frogoudakis, J. Bakallbashi, in: Nickel, World Production and Demand: Proceedings of the $3^{\text {rd }} \mathrm{Bal}$ kan Mining Congress (Balkanmine 2009), The Chamber of Mining Engineers of Turkey, Turkey, 2009, pp. 29-34.

4. Y. Chau, O. Kulikovsky-Cordeiro, Environ. Rev. 1995, 3, 95120. DOI:10.1139/a95-004

5. S. Sikdar, M. Kundu, ChemBioEng Rev. 2018, 5, 18-29. DOI:10.1002/cben.201700005

6. R. Eisler, Nickel hazards to fish, wildlife, and invertebrates: a synoptic review; Geological Survey Washington DC1998, https://www.pwrc.usgs.gov/eisler/CHR_34_Nickel.PDF, (assessed: June 05, 2019)

7. S. Dzugkoev, I. Mozhaeva, O. Margieva, A. Tedtoeva, F. Dzugkoeva, Sciences of Europe 2017, 2, 78-81.

8. Position Statement on Nickel Sensitivity (August 22, 2015), https://www.aad.org/Forms/Policies/Uploads/PS/PS-Nickel\%20Sensitivity.pdf (assessed: June 05, 2019)

9. J. P. Thyssen, Contact Dermatitis 2011, 65, 1-68. DOI:10.1111/j.1600-0536.2011.01957.x

10. M. Ghaedi, Spectrochim. Acta A 2007, 66, 295-301. DOI:10.1016/j.saa.2006.02.055

11. S. K. Kumar, P. S. Rao, L. Krishnaiah, B. Jayaraj, P. Chiranjeevi, Anal. Sci. 2004, 20, 951-953. DOI:10.2116/analsci.20.951

12. Z. Li, J. Pan and J. Tang, Anal. Lett. 2002, 35, 167-183. DOI:10.1081/AL-120002369

13. Y. Bazel, A. Tupys, Y. Ostapiuk, O. Tymoshuk, V. Matiychuk, J. Mol. Liq. 2017, 242, 471-477. DOI:10.1016/j.molliq.2017.07.047

14. D. Rekha, J. Kumar, B. Jayaraj, Y. Lingappa, P. Chiranjeevi, Bull. Korean Chem. Soc. 2007, 28, 373-378.

DOI:10.5012/bkcs.2007.28.3.373

15. C. Ramachandraiah, J. Rajesh Kumar, K. Janardhan Reddy, S. Lakshmi Narayana, A. Varada Reddy, J. Environ. Manage. 2008, 88, 729-736. DOI:10.1016/j.jenvman.2007.03.033

16. L. S. Sarma, J. R. Kumar, K. J. Reddy, T. Thriveni, A. V. Reddy, J. Trace Elem. Med. Bio. 2008, 22, 285-295. DOI:10.1016/j.jtemb.2008.06.003

17. C. Ravichandran, D. Benzil, C. Ramachandraiah, K. Chandrasekhar, Int. J. Bioassays 2015, 4, 4468-4472.

DOI: 10.21746/ijbio.2015.11.005.

18. K. Kuliev, N. Verdizade, S. Aliev, G. Suleymanova, World J. Pharmaceut. Res. 2018, 7, 61-73.

DOI: $10.20959 /$ wjpr201819-13762.

19. S. G. Aliyev, R. A. Ismailova, E. I. Suleymanova, L. M. Magarramova, S. S. Sultanzadeh, Z. G. Asgerova, A. Z. Zalov, Int. J. Innovat. Sci., Eng. Technol. 2018, 5, 192-206.

20. N. A. Verdizadeh and K. A. Kuliev, Izv. Saratov Univ. (N.S.), Ser. Chemistry. Biology. Ecology 2017, 17, 247-262.

DOI:10.18500/1816-9775-2017-17-3-247-262

21. M. Tuzen, M. Soylak, D. Citak, H. S. Ferreira, M. G. A. Korn, M. A. Bezerra, J. Hazard. Mat. 2009, 162, 1041-1045.

DOI:10.1016/j.jhazmat.2008.05.154 
22. W. N. L. dos Santos, D. D. Cavalcante, H. S. Ferreira, C. F. das Virgens, A. R. Borges, M. M. Silva, M. G. R. Vale, Int. J. Environ. Anal. Chem. 2011, 91, 1447-1452.

DOI:10.1080/03067319.2010.484885

23. M. Soylak, M. Tuzen, J. Hazard. Mat. 2008, 152, 656-661. DOI:10.1016/j.jhazmat.2007.07.027

24. S. A. Rocha and S. L. Ferreira, Eurasian J. Anal. Chem. 2007, 2, 1-11. DOI:10.12973/ejac/77011

25. Y.-S. Chung, W.-S. Chung, Bull. Korean Chem. Soc. 2003, 24, 1781-1784.

26. M. A. Zaitoun, A. K. El-Qisairi, K. A. Momani, H. A. Qaseer, W. Alhalasah, J. Environ. Occup. Sci. 2014, 3, 154-161. DOI:10.5455/jeos.20140909071020

27. M. Zaitoun, K. Momani, Q. Jaradat, I. Momani, I. Qurashi, Jordan J. Chem. 2014, 9, 81-96. DOI:10.12816/0026472

28. Y. Erdogdu, Ü. C. Başköse and S. Sağlam, Chem. Pap. 2019. DOI:10.1007/s11696-019-00739-4

29. K. B. Gavazov, T. S. Stefanova, Croat. Chem. Acta 2014, 87, 233-240. DOI:10.5562/cca2436

30. K. B. Gavazov, V. B. Delchev, K. T. Mileva, T. S. Stefanova, G. K. Toncheva, Acta Chim. Slov. 2016, 63, 392-398. DOI:10.17344/acsi.2016.2431

31. G. K. Toncheva, N. P. Milcheva, K. B. Gavazov, Acta Chim. Slov. 2018, 65, 847-852. DOI:10.17344/acsi.2018.4491

32. K. B. Gavazov, V. B. Delchev, N. P. Milcheva, G. K. Toncheva, Open Chem. 2019, 17, 599-608.

DOI:10.1515/chem-2019-0071

33. J. Patocka, K. Kuca, Mil. Med. Sci. Lett. 2012, 81, 142-163. DOI:10.31482/mmsl.2012.022.

34. A. Pal, V. Manish, S. Gupta, N. Kumar, SAE Tech. Pap. 2013, 2013-24-0151. DOI:10.4271/2013-24-0151

35. S. Atsumi, T. Hanai and J. C. Liao, Nature 2008, 451, 86-90. DOI:10.1038/nature06450

36. E. Löfström-Engdahl, On the diluent and solvent effects in liquid-liquid extraction systems based on bis-triazine-bipyridine (BTBP) ligands, PhD thesis, Chalmers University of Technology, Gothenburg, Sweden 2014, http://publications. lib.chalmers.se/records/fulltext/203658/203658.pdf (assessed: June 05, 2019)

37. C. E. Schaefer, X. Yang, O. Pelz, D. T. Tsao, S. H. Streger, R. J. Steffan, Chemosphere 2010, 81, 1111-1117.

DOI:10.1016/j.chemosphere.2010.09.002

38. J.-P. Mikkola, P. Virtanen, R. Sjoholm, Green Chem. 2006, 8, 250-255. DOI:10.1039/b512819f

39. K. B. Gavazov, G. K. Toncheva, Russ. J. Gen. Chem. 2015, 85, 192-197. DOI:10.1134/S1070363215010338
40. K. B. Gavazov, G. K. Toncheva, J. Adv. Chem. 2013, 5, 641-651.

41. L. Konermann, J. Am. Soc. Mass Spectrom. 2017, 28, 18271835. DOI:10.1007/s13361-017-1739-3

42. N. Menek, E. Eren, S. Topçu, Dyes Pigm. 2006, 68, 205-210. DOI:10.1016/j.dyepig.2005.01.010

43. D. D. Perrin, J. Chem. Soc. (Resumed) 1964, 3644-3648. DOI:10.1039/jr9640003644

44. A. S. Amin, Quim. Anal. 2001, 20, 145-151. DOI:10.1023/A:1008799422509

45. A. S. Amin, M. S. Ibrahim, Ann. Chim. (Rome) 2001, 91, 103110.

46. K. Ohshita, H. Wada, G. Nakagawa, Anal. Chim. Acta 1981, 124, 193-200. DOI:10.1016/S0003-2670(01)83913-1

47. F. Karipcin, E. Kabalcilar, Acta Chim. Slov. 2007, 54, 242-247.

48. F. Karipcin, B. Dede, S. Percin-Ozkorucuklu, E. Kabalcilar, Dyes Pigm. 2010, 84, 14-18.

DOI:10.1016/j.dyepig.2009.06.010

49. D. Nonova and B. Evtimova, Anal. Chim. Acta 1972, 62, 456461. DOI:10.1016/0003-2670(72)80058-8

50. H. Hoshino, T. Yotsuyanagi, K. Aomura, Anal. Chim. Acta 1976, 83, 317-328. DOI:10.1016/S0003-2670(01)84658-4

51. E. Asmus, Fresenius' J. Anal. Chem. 1960, 178, 104-116. DOI:10.1007/BF00467200

52. Z. Zhiming, M. Dongsten, Y. Cunxiao, J. Rare Earths 1997, $15,216-219$.

53. R. Vafazadeh, M. Namazian, B. Shahpoori-Arani, A. C. Willis, P. D. Carr, Acta Chim. Slov. 2018, 65, 372-379.

DOI:10.17344/acsi.2017.4096

54. X.-N. Fang, J. Li, X.-G. Yi, Q. Luo, J.-Y. Chen and Y.-X. Li, Acta Chim. Slov. 2019. DOI:10.17344/acsi.2018.4885

55. H. R. Hovind, Analyst 1975, 100, 769-796. DOI:10.1039/an9750000769

56. K. Pytlakowska, V. Kozik, M. Dabioch, Talanta 2013, 110, 202-228. DOI:10.1016/j.talanta.2013.02.037

57. W. Wei, C.-W. Cho, S. Kim, M.-H. Song, J. K. Bediako, Y.-S. Yun, J. Mol. Liq. 2016, 216, 18-24.

DOI:10.1016/j.molliq.2016.01.016

58. M. Atanassova, I. L. Dukov, Separ. Purif. Technol. 2004, 40, 171-176. DOI:10.1016/j.seppur.2004.02.007

59. V. Gardoňová, M. Labaška, I. Antalík, J. Kuruc, J. Radioanal. Nucl. Chem. 2013, 295, 1353-1360.

DOI:10.1007/s10967-012-1955-Z

60. A. G. Gaikwad, A. D. Damodaran, J. Radioanal. Nucl. Chem. 1992, 163, 277-288. DOI:10.1007/BF02034801

61. J. A. López-López, B. Herce-Sesa, C. Moreno, Talanta 2016, 159, 117-121. DOI:10.1016/j.talanta.2016.06.018 


\section{Povzetek}

Proučevali smo kromogen sistem ekstrakcije voda-izobutanol za NiI ${ }^{\mathrm{II}}$ na osnovi azo barvila 5-metil-4- (2-tiazolilazo) resorcinola $\left(\mathrm{MTAR} ; \mathrm{H}_{2} \mathrm{~L}\right)$ in ionske tekočine Aliquat 336 (A336). Pri uporabi optimalnih pogojev ekstrakcije $\left(c_{\mathrm{MTAR}}=2,0\right.$ $\cdot 10^{-4} \mathrm{~mol} \mathrm{dm}^{-3}, c_{\mathrm{A} 336}=5,6 \cdot 10^{-3} \mathrm{~mol} \mathrm{dm}^{-3}, \mathrm{pH} 8,5$ in čas ekstrakcije $\mathrm{t}=1 \mathrm{~min}$ ), se $\mathrm{Ni}^{\mathrm{II}}$ ekstrahira kot ternarna kompleksna spojina, ki jo lahko zapišemo s formulo $\left(\mathrm{A} 336^{+}\right)_{2}\left[\mathrm{Ni}\left(\mathrm{L}^{2-}\right)_{2}\right]$. V odsotnosti A336 ali v rahlo kislem mediju pride do nastanka binarne kompleksne spojine $\left[\mathrm{Ni}\left(\mathrm{HL}^{-}\right)_{2}\right]$, ki ima absorpcijski maksimum pri $\lambda=548 \mathrm{~nm}$, v spektru pa je opaziti tudi ramo pri $\lambda=590 \mathrm{~nm}$. Značilne ekstrakcijske in spektrofotometrične parametre smo določili pri optimalnih pogojih ekstrakcije: $\lambda_{\max }(545 \mathrm{~nm})$, molarna absorptivnost $\left(5,0 \cdot 10^{4} \mathrm{dm}^{3} \mathrm{~mol}^{-1} \mathrm{~cm}^{-1}\right)$, Sandellova občutlivost $\left(1,2 \cdot 10^{-3} \mu \mathrm{g} \mathrm{cm}-2\right)$, omejitve Beerovega zakona $\left(0,05-3,1 \mu \mathrm{g} \mathrm{cm}^{-3}\right)$, konstanta ekstrakcije $(\log K=6,1)$ in delež ekstrahirane frakcije $(99,2$ \%). Preučevali smo tudi vpliv dodanih ionov. Namočnejši vpliv v preučevanem sistemu so imeli $\mathrm{Co}^{\mathrm{II}}, \mathrm{Cu}^{\mathrm{II}}$ in $\mathrm{Cr}^{\mathrm{II}}$. 